\title{
Mapping Apple Orchards in the municipality of São Joaquim (Santa Catarina, Brazil) using Sentinel-2 data
}

\author{
Marcos Benedito Schimalski ${ }^{1}$, Leo Rufato ${ }^{2}$, Jessiane Mary Jastrombek ${ }^{3}$, Veraldo Liesenberg ${ }^{4}$ \\ Abstract - This study carried out a mapping procedure focusing on apple orchards considering the \\ planted area, spatial location, altitude range, slope interval, and presence of anti-hail nets in the city \\ of São Joaquim (Southern Santa Catarina Plateau, Brazil). Spectral images from the Sentinel-2 orbital \\ platform acquired in August 2018 and an enhanced digital elevation model from the Shuttle Radar \\ Topography Mission (SRTM) were used. In a GIS application configured with the SIRGAS 2000,4 \\ reference system and UTM cartographic projection, Sentinel-2 constellation images and digital elevation \\ models from the SRTM mission and more recently refined with sensor data Phased Array type L-band \\ Synthetic Aperture Radar (PALSAR) were added. All images were resampled to a spatial resolution of \\ $10 \mathrm{~m}$. The results were validated based on high spatial resolution images available from Google Earth. \\ The results show that São Joaquim has a planted area of 7,974.80 ha, and only $12 \%$ use an anti-hail \\ coverage system. The majority of the orchards range from one to five ha and belong to small producers. \\ More than $50 \%$ of the orchards are between 1,200 and 1,400 $\mathrm{m}$ in altitude, with $45 \%$ of orchards located \\ in areas with slopes between 8 to $20 \%$. Interestingly, most of the orchards are concentrated in a radius \\ of up to $20 \mathrm{~km}$ from the urban center of São Joaquim, where industries and cooperatives are located \\ for packaging, processing, and logistics. This study demonstrated that orbital data from Sentinel-2 \\ can effectively quantify the distribution of apple orchards, being a viable and effective alternative for \\ collecting information for agricultural monitoring. In this way, it enables efficient planning of apple \\ production, such as technical assistance, marketing with producers, and production flow. \\ Index terms: Apple tree culture; Fruit growing; Orchards; Remote Sensing; GIS.

\section{Mapeamento dos pomares de macieira no município de São Joaquim (Santa Catarina, Brasil) usando dados Sentinel-2}

\begin{abstract}
Corresponding author: jessianej@hotmail.com
\end{abstract}

Received: August 30,2021 Accepted : November 10, 2021

Copyright: All the contents of this journal, except where otherwise noted, is licensed under a Creative Commons Attribution License.

$(c c)) \mathrm{EY}$
Resumo - Este estudo realizou um mapeamento das áreas de pomares de macieira considerando área plantada, localização, altitude, declividade e o uso de cobertura antigranizo, no município de São Joaquim (Planalto Sul Catarinense, Brasil). Foram empregadas imagens espectrais da plataforma orbital Sentinel-2 adquiridas em agosto de 2018, e o modelo digital de elevação aprimorado do Shuttle Radar Topography Mission (SRTM). Em aplicativo GIS configurado com o sistema de referência SIRGAS 2000,4 e projeção cartográfica UTM, foram adicionadas as imagens da constelação Sentinel-2 e os modelos digitais de elevação advindos da missão SRTM refinados mais recentemente com dados do sensor Phased Array type L-band Synthetic Aperture Radar (PALSAR). Todas as imagens foram reamostradas para a resolução espacial de $10 \mathrm{~m}$. Os resultados foram validados com base em imagens disponíveis do Google Earth. Os resultados mostram que São Joaquim conta com área plantada de 7.974,80 ha de macieira, e destes $12 \%$ com sistema de cobertura antigranizo. A característica da região é de pequenos produtores em áreas de um a cinco ha. Um Percentual superior a 50\% dos pomares encontra-se no intervalo entre 1.200 e 1.400 $m$ de altitude. Com $45 \%$ dos pomares localizados em áreas com declividade entre 8 e $20 \%$. Em relação à localização, os pomares estão concentrados principalmente no raio de até $20 \mathrm{~km}$ de distância em relação ao centro urbano de São Joaquim, onde se encontra quase a totalidade das indústrias e cooperativas para o seu acondicionamento, beneficiamento e logística. Este estudo demonstrou que dados orbitais do Sentinel-2 podem quantificar efetivamente a distribuição dos pomares de macieira, sendo uma alternativa viável e eficaz no levantamento das informações para o monitoramento agrícola. Desse modo, viabiliza o planejamento eficiente da produção de maçã, como a assistência técnica, a comercialização com os produtores e o escoamento da produção.

Termos para indexação: Cultura da macieira; Fruticultura; Pomicultores; Sensoriamento remoto; GIS.

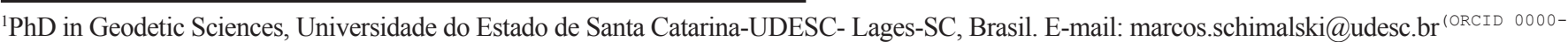
0001-7401-3881)

${ }^{2} \mathrm{PhD}$, Professor at the Graduate Program in Plant Production, Universidade do Estado de Santa Catarina-UDESC-Lages-SC, Brasil. E-mail: ruffato@yahoo.com.br ${ }^{\text {(ORCID 0000-0001-9545-7035) }}$

${ }^{3}$ M.Sc, in Plant Production. Universidade do Estado de Santa Catarina - UDESC - Lages - SC, Brasil. E-mail: jessianej@hotmail.com ${ }^{\text {(ORCID }}$ 0000-0002-4337-5190)

${ }^{4} \mathrm{PhD}$ in Environmental Geosciences, Universidade do Estado de Santa Catarina - UDESC - Lages - SC, Brasil. E-mail: veraldo.liesenberg@ $\underline{\text { udesc.br }^{\text {(ORCID }} \text { 0000-0003-0564-7818) }}$
} 


\section{Introduction}

The apple tree (Malus domestica Borkh) crop stands out in the Brazilian fruit growing scenario, moving the national economy with a cultivated area, estimated based on statistical yearbooks, of 32,405 ha (IBGE, 2019). Apple production is concentrated in the southern region due to the region's altitude and temperate climate, favoring the crop's development (PETRI et al., 2021). Rio Grande do Sul (RS) and Santa Catarina (SC) states are the largest producers with an estimated area of 15,889 ha and an annual production of $603,209 \mathrm{Mg}$ (tonnes), followed by 15,198 ha and a production of $585,790 \mathrm{Mg}$, respectively (IBGE, 2019). The municipality of São Joaquim-SC is the largest apple producer nationwide. Currently, it has approximately 8,200 ha of orchards devoted to apple trees, distributed among 2,072 producers, with an average annual production of $350,000 \mathrm{Mg}$ (AMAP, 2020). However, such statistics are purely based on interviews and are not supported by remote sensing images.

São Joaquim has its economic base in cultivating fruit trees, mainly apple trees, with pomiculture responsible for approximately $70 \%$ of the municipality's gross domestic product (GDP) (ZANELA, 2019). The apple tree culture is cultivated by small and medium rural producers and companies that operate throughout the cycle (production, processing, and commercialization) (MARTIN et al., 2019).

The region's cold climate favors the production of temperate fruit trees, such as apple trees, providing better quality fruit. However, the region faced frequent hailstorm events, causing damage to orchards. Due to this, producers use the apple tree production system under an anti-hail net (HAWERROTH; NACHTIGALL, 2019). According to Kist et al. (2019), around $20 \%$ of the apple production areas in Brazil rely on the system, mainly in the regions around the cities of São Joaquim-SC and Vacaria-RS.

Regional agricultural surveys are carried out for data collection from fruit-bearing areas, registered by extension technicians and collaborators (TRAMBAQUINI et al., 2011). This information is recorded in spreadsheets, which are later compiled, allowing quantification for an entire region. However, the degree of information on the location and dimension of orchards in the region is still incipient. Still, there is no certainty about the information's timeliness and whether all rural producers were visited. In short, such information is critical for efficient planning of harvest logistics, such as the allocation of bins, trucks for transport, and chiller rooms for storage.

With the recent digital processing techniques of remotely obtained images, it is possible to determine the spatial distribution of orchards (ZHU et al., 2020), also providing visualizing and identifying the areas of crops with comprehensive monitoring, continuously monitoring, in a shorter time and lower operating cost. Furthermore,
GIS applications allow, through geoprocessing techniques, to precisely establish the dimensions of the orchards and the distances from the county seat, optimizing resources to support the supply chain.

In this context, this research proposes a mapping procedure method using spectral images from the Sentinel-2 constellation to quantify the spatial distribution of apple orchards in the city of São Joaquim-SC. Additionally, these orchards were characterized by an anti-hail net, topographic attributes, and distance from the urban center.

\section{Material and methods}

\section{Description of the study área}

São Joaquim is a Brazilian municipality in SC with a surface of $1,886 \mathrm{~km}^{2}$. The central coordinates are $28^{\circ} 17^{\prime} 38^{\prime \prime} \mathrm{S}$ and $49^{\circ} 55^{\prime} 54^{\prime \prime} \mathrm{W}$, with an orthometric height of $1,354 \mathrm{~m}$. It is the highest city in Santa Catarina considering the municipal seat's altitude, whose value ranges from $1,300 \mathrm{~m}$ to $1,450 \mathrm{~m}$ in its urban area (Figure $1)$. The city's climate is maritime temperate $(\mathrm{Cfb})$, with cool summers and low winter temperatures and rainfall well distributed throughout the year, without a dry season (ALVARES et al., 2014).

To determine the spatial distribution of apple orchards, images acquired by the Sentinel-2A/ MSI (Multispectral Instrument) orbital platform on August 28, 2018, consisting of two tiles, were processed: 1) L1C_T22JEP_A016623_20180828T132231 and 2L1C T22JFP_A016623_20180828T132231, respectively. The spectral images were obtained from the Copernicus Open Access Hub portal. The characteristics of the spectral bands and other detail are available in ESA (2007).

The spectral images were obtained at level 1C, that is, data with reflectance at the top of the atmosphere (TOA). Next, using the Sen2cor plugin available in the Sentinel Application Platform (SNAP) application, the images were processed to level $2 \mathrm{~A}$, with reflectance at the bottom of the atmosphere (BOA). Then, the images were resampled (nearest neighbor) to a spatial resolution of 10 meters using the computer application SNAP. Finally, it was decided to process the two images in a digital mosaic resulting in a multispectral file with a spatial resolution of $10 \mathrm{~m}$ and 12 spectral bands.

To support visual interpretation, a false-color composition was defined combining the following spectral bands: B12 (2,190 nm; shortwave infrared), B11 (1610 $\mathrm{nm}$; shortwave infrared), and B4 $(665 \mathrm{~nm}$; red). This combination was obtained by calculating the Optimum Index Factor (OIF). This index was initially proposed by CHAVEZ et al. $(1982,1984)$, and it takes into account the statistics of samples collected from different locations in the study area. A detailed analysis of the OIF, including a demonstration of its calculation and other procedures, can be found in JENSEN (2009). 


\section{Geographic Location}
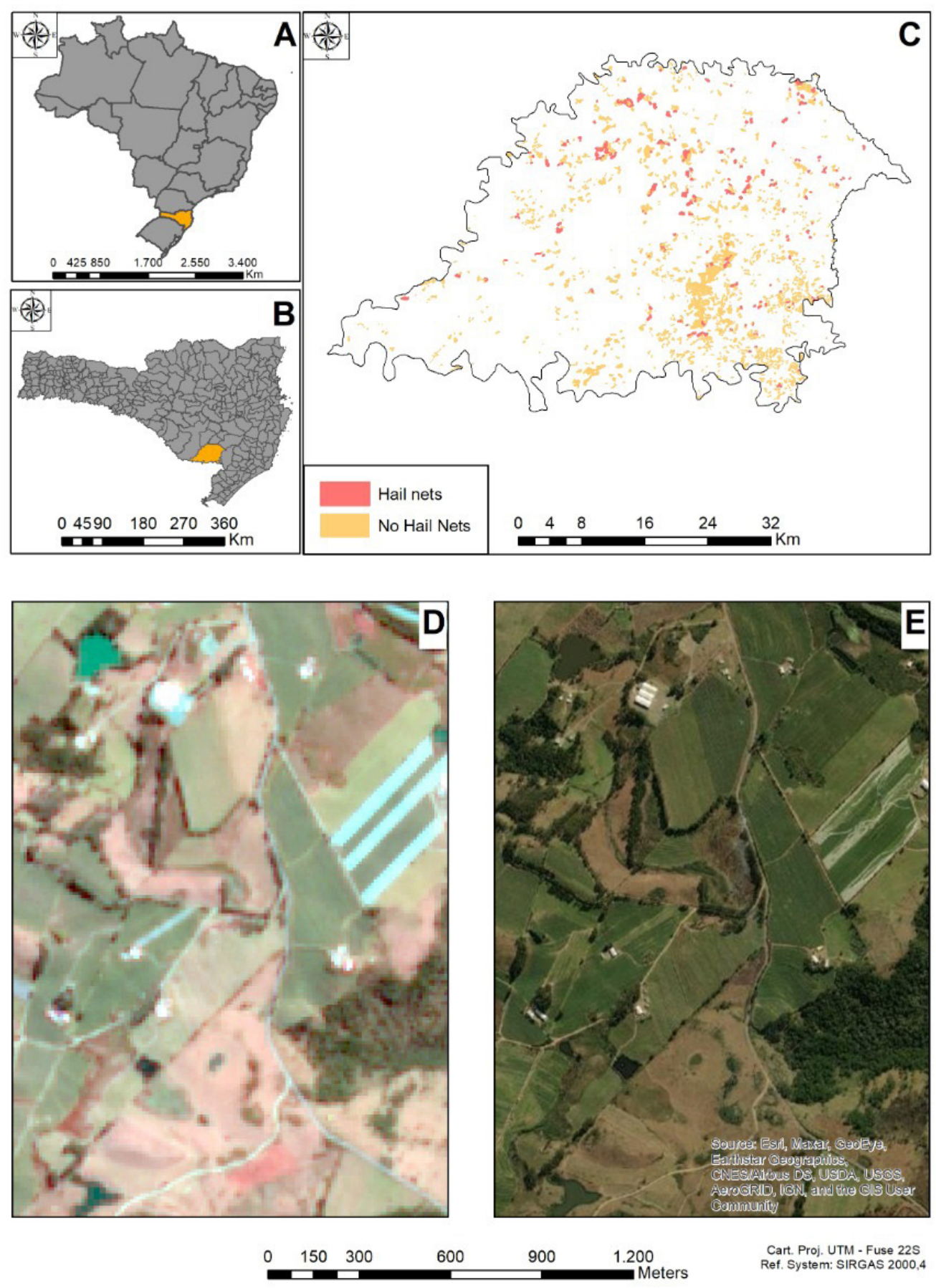

Figure 1. Location map of the study area within the national (A) and state (B) contexts. An overview of the spatial distribution of orchards in the city of São Joaquim-SC (C). A subset of Sentinel-2 (R4G3B2) for a rural property containing apple orchards with and without hail nets (D). The cyan color highlights the contrast of apple trees with hail nets, whereas orchards without hail nets are shown in green color. The same area is shown in a high spatial resolution image subset available from Google Earth@ (E). 
data

\section{Acquisition and processing of Remote Sensing}

The following parameters were configured in the ArcGIS 10.4® software: SIRGAS 2000,4 (Geocentric Reference System for the Americas) and UTM (Universal Transverse Mercator) cartographic projection on zone 22S. Next, the Sentinel-2 mosaic (Figure 1D) and the Google Earth base map (Figure 1E) were added as a matrix layer. Then, a visual interpretation key was performed to identify the apple orchards. Subsequently, vectorization tools were used to delineate the apple orchards and label them for the presence or absence of anti-hail nets. In Figure 1D, it is possible to visualize, in the cyan color, the contrast of the orchards with anti-hail coverage. On the other hand, the same subset shows a predominantly green coloration for orchards without anti-hail nets.

Complementarily, surface reflectance spectral profiles were also used to categorize the presence or absence of anti-hail nets in certain regions. In addition, some metrics were extracted from the digital elevation model (DEM) SRTM improved with data from the Phased Array type L-band Synthetic Aperture Radar (PALSAR) sensor. This DEM was enhanced based on radiometric and geometric corrections performed by the Alaska Satellite Facility (ASF). It consists basically of refinement of NASA's Space Shuttle Radar Topographic Mission (SRTM) (MOREIRA, 1995; WERNE, 172 2001; RABUS, 2003).

Three DEM scenes were considered, namely 167 AP_02392_FBS_F6600_RT1, AP_02567_FBS_F6610_ RT1 and 168 AP_05426_FBS_F6610_RT1. The DEM in question has a geometric resolution of $12.5 \mathrm{~m}$, geographic coordinate system WGS84 obtained from the ASF ALASKA website [ASF Home Page: https://asf.alaska. edu]. The three DEMs were mosaiced and resampled to a spatial resolution of $10 \mathrm{~m}$ and keeping the nearest neighbor interpolator. A subset was then performed for all the aforementioned data, considering the Brazilian Institute of Geography and Statistics (IBGE) for 2017 (IBGE, 2021).

For the hypsometric classes, we chose to use the intervals in six thematic classes, considering $200 \mathrm{~m}$ intervals, such as: a) 724 to $800 \mathrm{~m}$, b) 800 to $1,000 \mathrm{~m}, \mathrm{c}$ ) $1,000$ to $1,200 \mathrm{~m}, \mathrm{~d}) 1,200$ to $1,400 \mathrm{~m}, \mathrm{e}) 1,400$ to 1,600 $\mathrm{m}$ and f) 1,600 to $1,678 \mathrm{~m}$. The slopes were calculated and reclassified in intervals as proposed by EMBRAPA (1979). The slope exposure map was created considering the $45^{\circ}$ interval for each section of the eight cardinal points.

For the last analysis, buffers were created from the center of the city of São Joaquim using the following radii: a) $5 \mathrm{~km}$, b) $10 \mathrm{~km}$, c) $20 \mathrm{~km}$, d) $30 \mathrm{~km}$, e) $40 \mathrm{~km}$, and f) $50 \mathrm{~km}$. Finally, an intersection of these buffers with the orchard polygons allowed to obtain the statistics in each radius.

\section{Results and discussion}

\section{Apple Orchard Mapping}

The proposed approach accurately identified the apple orchards. However, other cultivated fruit species with similar characteristics were also identified in the study area. Among them, plums and vines also use antihail nets, which may generate a variation, around 1\% of the apple orchards estimation reported in this study. Interestingly, studies carried out by Zhu et al. (2020) identified apple orchards using Sentinel-2 images and reported that no phenological differences were identified between apple and cherry trees in orchards located in Qixia, Shandong Province, China.

The changes in surface reflectance of orchards with and without hail nets are shown in Figure 2A. In general, anti-hail nets, predominantly white in color, tend to preserve the typical features of green vegetation. However, there is a regular displacement as the material potentiates the backscattering of electromagnetic radiation from apple trees. A subset of the study area by Google Earth shows a perspective of a typical rural property (Figure 2B). In addition, the same subset is shown in Sentinel-2 true color (R4G3B2) (Figure 2C) and false-color (R12G3B2) (Figure 2D) compositions.

In the mapping procedure carried out through the visual interpretation of the Sentinel-2 images, it can be observed that the municipality of São Joaquim has 7,974.80ha of apple orchards (Table 1). In summary, 940.43ha of the orchards are covered with the anti-hail net system $(11.79 \%)$, whereas $7,034.37$ ha are not covered (88.21\%). Such numbers disagree with the estimates provided by Kist et al. (2019) that reported that around $20 \%$ of the apple production areas in Brazil rely on antihail systems.

The location and distribution of apple orchards observed on the map, in general, are distributed throughout the municipality, from north to south and east to west (Figure 3). The largest number of orchards are found in green color, i.e., without using the anti-hail net. In red color, the orchards with anti-hail nets are shown. 

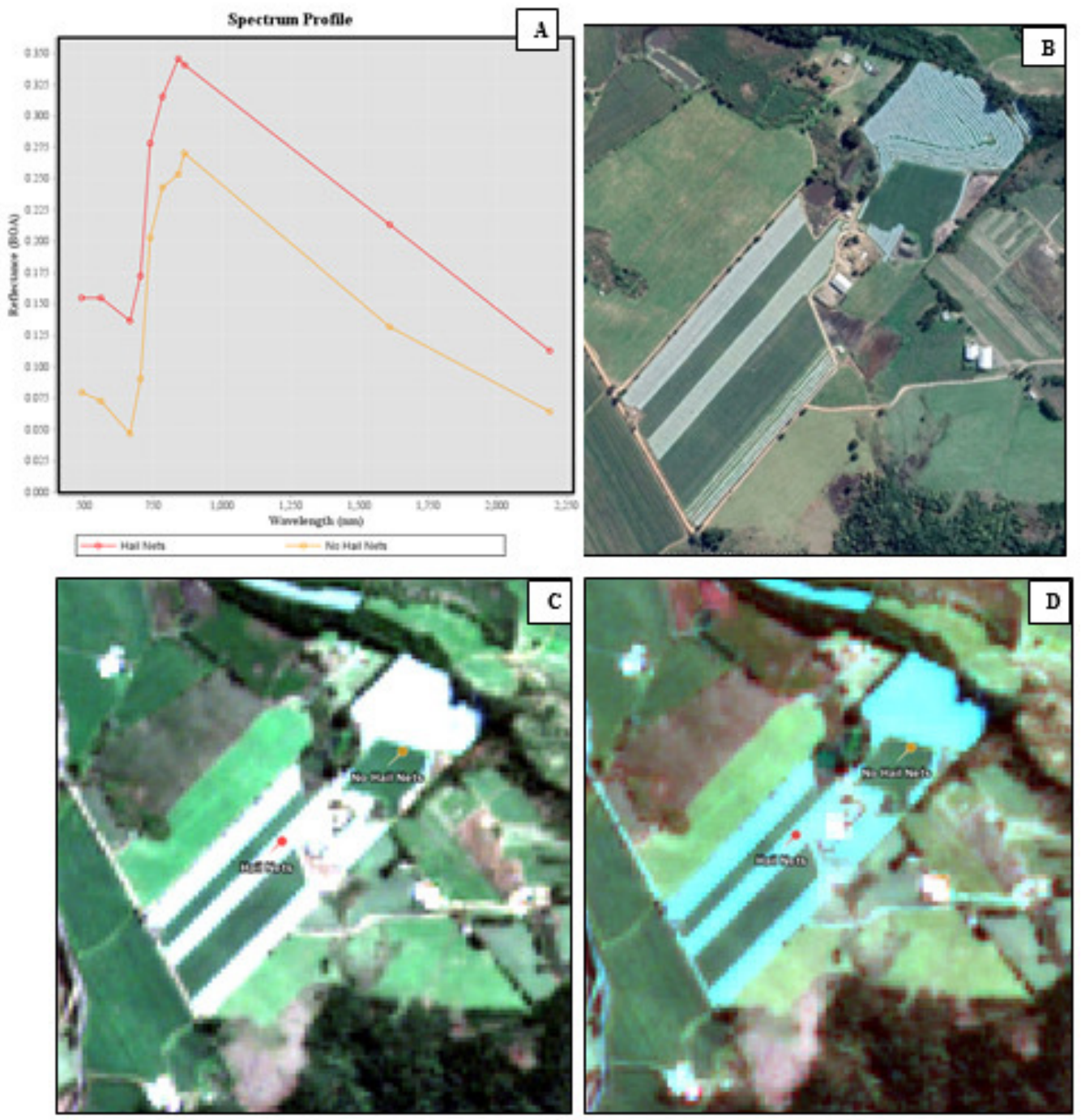

Figure 2. Sentinel-2 surface reflectance spectra of apple orchards in the presence and absence of anti-hail net (A); a subset of the study area by Google Earth (B); Sentinel-2' true color (R4G3B2) (C); and false-color (R12G3B2) compositions (D).

Table 1. Size of areas of apple orchards, with and without anti-hail nets and total area in hectares, in the municipality of São Joaquim-SC.

\begin{tabular}{ccccccc}
\hline Size & \multicolumn{2}{c}{ With anti-hail net } & \multicolumn{2}{c}{ Without anti-hail net } & \multicolumn{2}{c}{ Total Area } \\
\hline ha & ha & $\%$ & ha & $\%$ & ha & $\%$ \\
\hline até 1 & 84.94 & 1.07 & $1,021.34$ & 12.81 & $1,106.34$ & 13.87 \\
1 a 5 & 538.33 & 6.75 & $4,556.98$ & 57.14 & $5,095.31$ & 63.89 \\
> 5 & 317.15 & 3.98 & $1,456.04$ & 18.26 & $1,773.19$ & 22.24 \\
Total & $\mathbf{9 4 0 . 4 3}$ & 11.79 & $\mathbf{7 , 0 3 4 . 3 7}$ & 88.21 & $\mathbf{7 , 9 7 4 . 8 0}$ & 100.00 \\
\hline
\end{tabular}


It is important to mention that in São Joaquim, there is a higher frequency of hail events, causing damage to apple tree flowering and deforming the fruits. It may also cause lesions in larger fruits favoring the entry of pathogens. As a result, it compromises both quality and production (HAWERROTH; NACHTIGALL, 2019).
According to IBGE data (2019), the average apple yield in São Joaquim was $40 \mathrm{Mg}$.ha ${ }^{-1}$, with an average price paid to the producer of $\mathrm{R} \$ 1.10 \mathrm{Kg}^{-1}$. Thus, the loss of production caused by hailstorms can reach $\mathrm{R} \$ 44,000.00$ ha $^{-1}$ (HOFFMANN, 2020). Therefore, these losses and damages caused to the fruit's quality can be minimized by using anti-hail nets (STOKA et al., 2021).

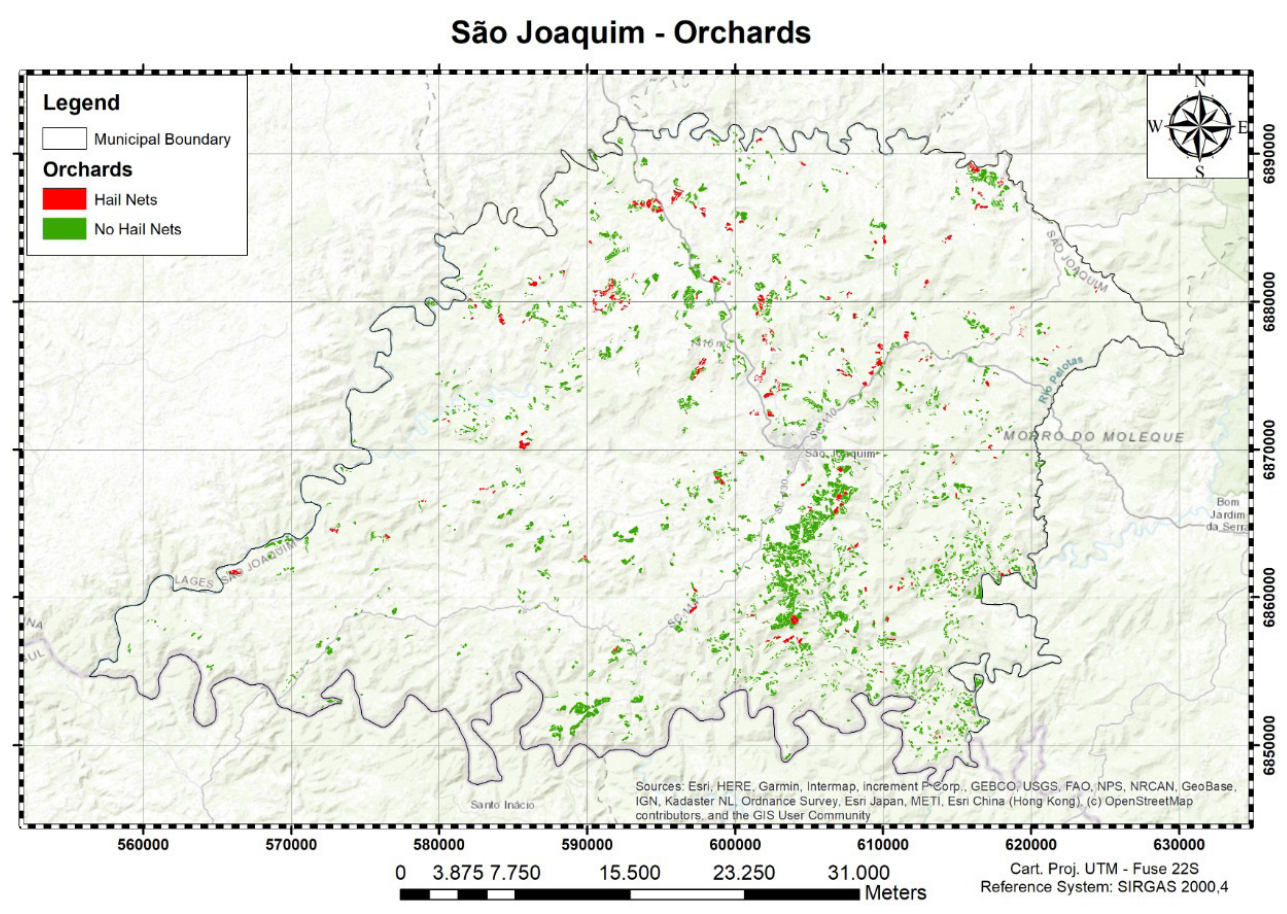

Figure 3. Map of the location of apple orchards, with and without the anti-hail net, in the municipality of São JoaquimSC.

Regarding the size of the orchards, most of the areas ranged from one to five ha (64\%; Table 1$)$. Therefore, the anti-hail net system covers only $7 \%$ of these orchards. According to Martin et al. (2019), a particular feature of the São Joaquim orchards is related to the individual quality of the apple fruit. The authors argue that this aspect is strongly associated with the production system adopted by small rural properties.

Orchards above five ha represent $4 \%$ in areas with and $18 \%$ without anti-hail nets. In smaller quantities, orchards with up to one ha are also observed (Table 1). According to AMAP (2020) data, São Joaquim has 2,072 producers and an average production of $350,000 \mathrm{Mg}$. Thus, small producers are responsible for most of the orchards, representing more than $50 \%$ of the total apples produced in the municipality and more than $30 \%$ of the national production (MARTIN et al., 2019). For Damasceno et al. (2019), in São Joaquim, there is a predominance of small producers, characterized by familiar labor, providing adequate and quality management throughout the harvest with lower labor costs.

\section{Characterization of orchards according to relief}

Regarding altitude, the orchards are mainly concentrated from 1,000 to $1,600 \mathrm{~m}$ (Figure 4A). But, remarkably, more than $50 \%$ of the orchards are found in the range between 1,200 and $1,400 \mathrm{~m}$ (Table 2). Moreover, $44,3 \%$ of the orchards are without anti-hail nets at this particular range, while $5.4 \%$ with anti-hail nets. 
Table 2. The altitude of apple orchards, with and without anti-hail nets in the municipality of São Joaquim-SC.

\begin{tabular}{ccccccc}
\hline Altitude & \multicolumn{2}{c}{ With anti-hail net } & \multicolumn{2}{c}{ Without anti-hail net } & \multicolumn{2}{c}{ Total area } \\
\hline metros & ha & $\%$ & ha & $\%$ & ha & $\%$ \\
\hline 724 a 800 & - & - & 3.42 & - & 3.42 & 0.04 \\
800 a 1.000 & 56.26 & 0.71 & 355.45 & 4.46 & 411.71 & 5.16 \\
1.000 a 1.200 & 331.49 & 4.16 & $2,612.28$ & 32.76 & $2,943.77$ & 36.91 \\
1.200 a 1.400 & 430.45 & 5.40 & $3,527.83$ & 44.24 & $3,958.28$ & 49.63 \\
1.400 a 1.600 & 122.22 & 1.53 & 532.74 & 6.68 & 654.96 & 8.21 \\
1.600 a 1.678 & - & - & 2.38 & - & 2.38 & 0.03 \\
\hline Total & $\mathbf{9 4 0 . 4 3}$ & 11.79 & $\mathbf{7 , 0 3 4 . 3 7}$ & 88.21 & $\mathbf{7 , 9 7 4 . 8 0}$ & 100.00 \\
\hline
\end{tabular}

Interestingly, it is possible to identify the effect of altitude on the apple fruits (Amarante, 2012). According to this author, São Joaquim, with higher altitude, favors metabolic and physiological processes, providing fruits with quality and firmness of pulp, suitable for storage and post-harvest. Complementarly, Bittencourt (2011) described that the cold climate of São Joaquim, caused by the high altitude, provides a more significant accumulation of sugars and more awesome coloring to apple fruits. This behavior is due to the prolongation of the cycle, providing late harvesting. In summary, the temperature range and cooler night temperatures in pre-harvest promote the synthesis of anthocyanins, improving the intensity and increasing the color of the fruits.

It is worth mentioning that the fuji is the most demanding cultivar in terms of cold. This is because the highest areas and lower temperatures, such as those in São Joaquim, result in the accumulation of cold that favors the fruits' size, shape, and color (PETRI et al., 2011; RECH, 2014).

According to Martin et al. (2019), the greater accumulation of cold benefits the physiology of the apple tree and the morphology of the flowers, providing the fruits with a well-developed peduncle and an elongated fruit. However, for regions with lower altitudes, less rigorous winters, and warmer temperatures in spring, such as Fraiburgo (SC), the fruits tend to be smaller, flattened, less intensely colored, and with lower productivity (PETRI et al., 2021).
The apple fruits produced in the region of São Joaquim are considered superior quality by the market and, more recently achieved, the designation of origin and geographical indications safeguard (EPAGRI, 2021). According to EPAGRI (2021), this was possible due to the climatic factors, altitude range, number of chill hours, and the high percentage of family labor.

Moreover, almost all apple orchards are found on a gentle wavy to wavy slope, with up to $20 \%$ slope $(80 \%$; Table 3). The DEM also reveals that $44 \%$ of orchards are found within the slope range of 8 to $20 \%$. The use of anti-hail net accounts for $5 \%$ of orchards in this particular range, while the absence for the remaining 39\%. Steeper areas ranging from 45 to $75 \%$ accounted for less than $1 \%$ of the orchards (Figure 4B; Table 3). Complex topography makes mechanization difficult, being those few areas associated with small properties where manual harvesting is usually adopted (PEREIRA et al., 2010). In this sense, the characteristic of the São Joaquim relief favors the production of apple orchards, making it economically viable for small rural properties due to their climatic conditions, thus providing quality products for the apple production sector.

Table 3. Slope intervals of the apple orchards, with and without anti-hail nets in the city of São Joaquim-SC.

\begin{tabular}{ccccccc}
\hline Class of slope & \multicolumn{2}{c}{ With anti-hail net } & \multicolumn{2}{c}{ Without anti-hail net } & \multicolumn{2}{c}{ Total area } \\
\hline$\%$ & ha & $\%$ & ha & $\%$ & ha & $\%$ \\
\hline 0 a 3 & 75.98 & 0.95 & 557.46 & 6.99 & 633.44 & 7.94 \\
3 a 8 & 287.88 & 3.61 & $1,978.34$ & 24.81 & $2,266.22$ & 28.42 \\
8 a 20 & 418.59 & 5.25 & $3,077.12$ & 38.59 & $3,495.71$ & 43.83 \\
20 a 45 & 156.18 & 1.96 & $1,397.89$ & 17.53 & $1,554.07$ & 19.49 \\
45 a 75 & 1.78 & 0.02 & 23.11 & 0.29 & 24.88 & 0.31 \\
$>$ 75 & - & - & - & - & - & - \\
\hline Total & $\mathbf{9 4 0 . 4 3}$ & 11.79 & $\mathbf{7 , 0 3 4 . 3 7}$ & 88.21 & $\mathbf{7 , 9 7 4 . 8 0}$ & 100.00 \\
\hline
\end{tabular}


Figure 4C shows the slope orientation (aspect), where $15.5 \%$ of the orchards are located to NW and $13.4 \%$ to $\mathrm{N}$ (Table 4 ). The anti-hail screes respond for $\sim 2 \%$ each for both aspects. For Cunha and Bacani (2015), slopes facing $\mathrm{N}$ receive more intense solar radiation than those facing $\mathrm{S}$, favoring solar incidence. In this way, they are protected from the intensity of the winds coming from the $\mathrm{S}$ face. For Stoka et al. (2021), the shading in plants influenced by more frequent cloudy days and abundant rains reduces the photosynthetically active radiation, therefore reducing the plant's photosynthetic capacity.
Thus, the cultivation of apple orchards is an adequate alternative to surface conditions with a natural inclination, according to the instability of the topographical variations of the area and shallow soils. However, areas with a predominance of slopes require adequate management due to infiltration with low drainage capacity, accentuated by the frequency of rain. Moreover, for Petri et al. (2019) and Bauer et al. (2020), the symptoms of diseases and disorders prevalent in apple orchards are frequent in shady and humid places, influenced by low temperatures and reduced levels of light.

Table 4. Slope orientation of apple orchards, with and without anti-hail nets in the municipality of São Joaquim-SC.

\begin{tabular}{ccccccc}
\hline \multirow{2}{*}{ Slope orientation } & \multicolumn{2}{c}{ With anti-hail net } & \multicolumn{2}{c}{ Without anti-hail net } & \multicolumn{2}{c}{ Total area } \\
\cline { 2 - 7 } & ha & $\%$ & ha & $\%$ & ha & $\%$ \\
\cline { 2 - 7 } Norte & 156.43 & 1.96 & 911.87 & 11.43 & $1,068.30$ & 13.40 \\
Nordeste & 114.98 & 1.44 & 821.54 & 10.30 & 936.52 & 11.74 \\
Leste & 81.63 & 1.02 & 750.53 & 9.41 & 832.16 & 10.43 \\
Sudeste & 68.66 & 0.86 & 766.64 & 9.61 & 835.30 & 10.47 \\
Sul & 98.19 & 1.23 & 882.10 & 11.06 & 980.29 & 12.29 \\
Sudoeste & 117.09 & 1.47 & 901.66 & 11.31 & $1,018.75$ & 12.77 \\
Oeste & 133.50 & 1.67 & 932.53 & 11.69 & $1,066.04$ & 13.37 \\
Noroeste & 169.93 & 2.13 & $1,067.04$ & 13.38 & $1,236.33$ & 15.51 \\
\hline Total & $\mathbf{9 4 0 . 4 3}$ & 11.79 & $\mathbf{7 , 0 3 4 . 3 7}$ & 88.21 & $\mathbf{7 , 9 7 4 . 8 0}$ & 100.00 \\
\hline
\end{tabular}

\section{Characterization of orchards regarding logistics}

Figure 4D shows the distribution of the apple orchards concerning the urban center of São Joaquim. In general, the orchards are mainly concentrated up to $20 \mathrm{~km}$, where $70 \%$ of the orchards are still without any anti-hail system, whereas only $10 \%$ of the orchards accounted for the coverage system (Table 5).
Three of the large apple-producing centers are located in the country's southern region, namely in São Joaquim and Fraiburgo (SC) and Vacaria (RS). Companies located in this region have been seeking quality and product development, as they have vertical production with a packing house for processing and large storage capacity (RECH, 2014; BUENO, 2021). Therefore, these companies such as Fischer (Fraiburgo) and Schio (Vacaria), the largest companies in the apple sector, aim to buy apples produced by small and medium producers, mainly in São Joaquim, due to the peculiarity of the apples produced (BITTENCOURT, 2011; SALATINO et al., 2018).

Table 5. Distance of apple orchards in relation to the center of São Joaquim-SC.

\begin{tabular}{ccccccc}
\hline Distance to the center & \multicolumn{2}{c}{ With anti-hail net } & \multicolumn{2}{c}{ Without anti-hail net } & \multicolumn{2}{c}{ Total area } \\
\hline metros & ha & $\%$ & ha & $\%$ & ha & $\%$ \\
\hline 5 & 91.68 & 1.15 & 629.81 & 7.90 & 721.49 & 9.05 \\
10 & 160.21 & 2.01 & $1,596.96$ & 20.03 & $1,757.17$ & 22.03 \\
20 & 514.94 & 6.46 & $3,385.70$ & 42.45 & $3,900.64$ & 48.91 \\
30 & 137.94 & 1.73 & $1,234.15$ & 15.48 & $1,372.09$ & 17.21 \\
40 & 35.66 & 0.45 & 157.58 & 1.98 & 193.24 & 2.42 \\
50 & - & - & 30.17 & 0.38 & 30.17 & 0.38 \\
\hline Total & $\mathbf{9 4 0 . 4 3}$ & 11.79 & $\mathbf{7 , 0 3 4 . 3 7}$ & 88.21 & $\mathbf{7 , 9 7 4 . 8 0}$ & 100.00 \\
\hline
\end{tabular}


To receive the apple purchased from producers in the region right after the harvest, Schio company maintains a packing house with storage capacity in São Joaquim. In turn, the Fischer group moves the production of apples purchased from producers in São Joaquim over $245 \mathrm{~km}$ to the company's packing house in Fraiburgo (BITTENCOURT, 2011).
In this way, the flow of apple production can be efficiently planned for marketing with producers in São Joaquim, considering that $80 \%$ of producers are within a distance of $20 \mathrm{~km}, 17 \%$ are within $30 \mathrm{~km}$, and only $2.4 \%$ to $40 \mathrm{~km}$ away. Furthermore, by determining the current apple orchard's size, it is possible to estimate roughly the apple fruit production, making it possible to estimate the allocation of bins, trucks for transport, and chiller room for apple storage.

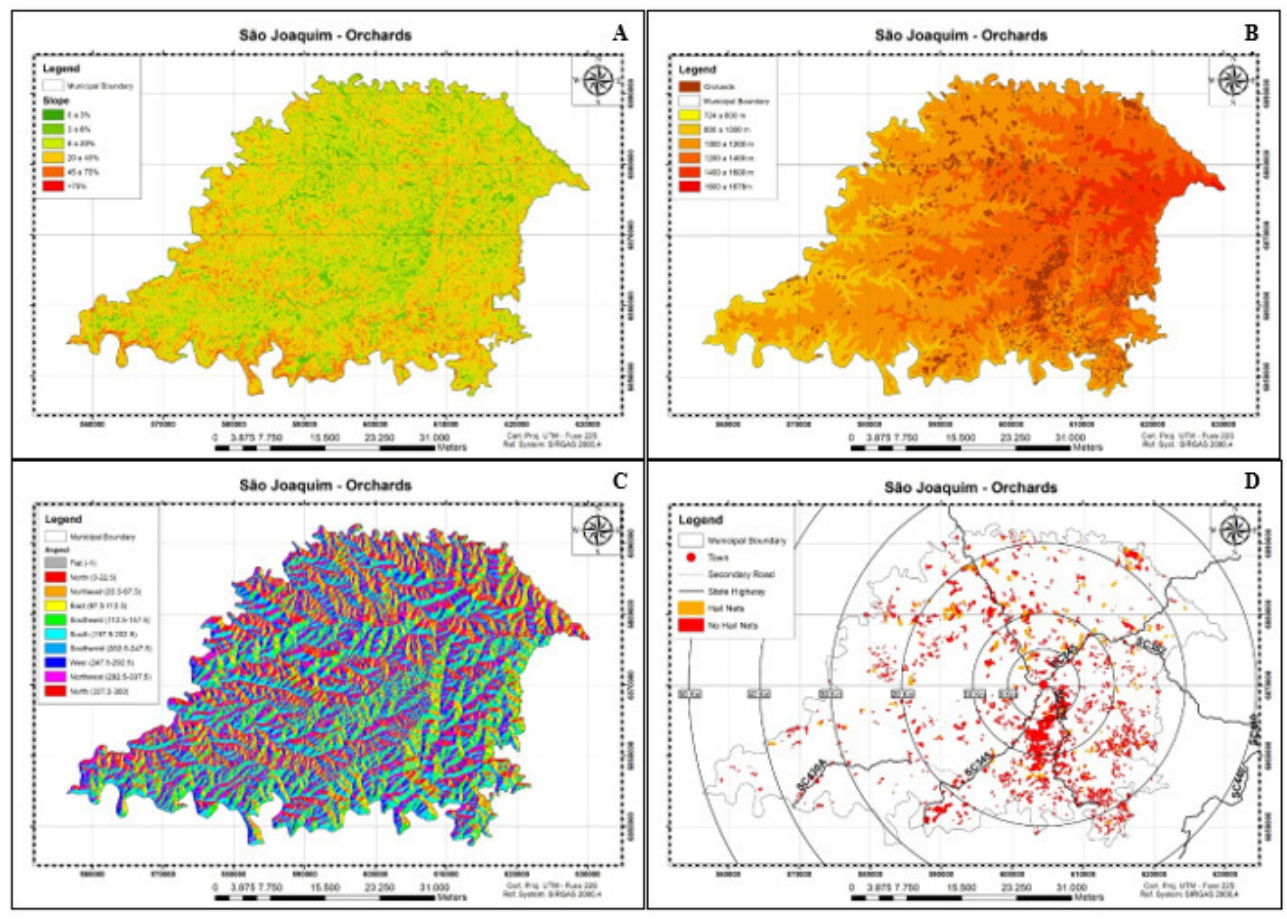

Figure 4. Maps of the municipality of São Joaquim (SC). Hypsometric map (A), Slope map (B), Slope exposure (C), and map of the distance to the urban center of the city of São Joaquim (D).

\section{Perspectives for future studies}

Remote Sensing in fruit growing aims to further boost the sector's technological innovations, mainly in recognizing orchards. Current machine learning methods combined with high spatial and temporal resolution images offer new perspectives for orchards monitoring. In this way, coupled with geoprocessing techniques, orchard location maps can be generated, facilitating the search for these areas and establishing temporal monitoring initiatives to update the cartographic database.

Considering that studies with Remote Sensing aimed at fruit growing areas are still incipient, images of Unmanned Aerial Vehicles (UAVs) and artificial satellites are still under constant development in the fruit growing area. Therefore, detailed methodological studies, producers, and consumers are still needed to provide a valuable data source for companies in the fruit sector.
Other initiatives are already being developed, such as aerial and terrestrial photographs for the detection of fruits and health in orchards (BIFFI et al., 2021ab). Given this, the continuity of this study can contribute to updating the areas of apple orchards, pointing to the expansion of orchards and the use of anti-hail coverage for the municipality of São Joaquim, then in the future in Santa Catarina and nationwide. In this way, based on the improved methodology and partnerships with field validation, we would like to monitor the grape growing in the region. 


\section{Conclusions}

This study made it possible to identify a planted area of 7,974.80 ha of apple orchards in São Joaquim, where $12 \%$ of this area has an anti-hail net system. More than $50 \%$ of the orchards ranging from one to five ha are in small rural properties, located mainly up to $20 \mathrm{~km}$ away from the urban center of São Joaquim and at an altitude of 1,200 to $1,400 \mathrm{~m}$.

We also demonstrated that technological innovation tools such as Remote Sensing could effectively quantify the spatial distribution of apple orchards, being a viable and effective alternative in collecting information for supporting agricultural monitoring initiatives.

Based on data from the spatial distribution of apple orchards, it is possible to manage and efficiently plan apple fruit production. Some examples are suggested, such as development policies, technical assistance, marketing with producers, and production flow. Thus, it is possible to program the harvest logistics, such as allocating bins and trucks for transport and estimating apple cold storage plants.

\section{Acknowledgments}

This research was partially funded by the Santa Catarina Research Foundation (FAPESC; 2017TR1762; 2020TR713, and PAP/UDESC). VL thanks the Brazilian National Council for Scientific and Technological Development for individual support (CNPq; 313887/20187 ; 436863/2018-9).

\section{References}

ABPM - Associação Brasileira de Produtores de Maçã. Maçã. Fraiburgo, 2020. Disponível em: https://www. abpm.org.br/ Acesso em: 15 mar. 2021.

ALVARES, C.A; STAPE, J.L; SENTELHAS, P.C; GOLÇALVES, J.L.M; SPAROVEK, G. Köppen's mapa de classificação climática para o Brasil. Meteorological Journal, Stuttgart, v.22, p.711-728, 2014.

AMARANTE, C.V.T.; ARGENTA, L.C.; BASSO, C.; SUZUKI, A. Composição mineral de maçãs 'Gala' e 'Fuji' produzidas no Sul do Brasil. Pesquisa Agropecuária Brasileira, Brasília, DF, v.47, n.4, p.550-560, 2012.

BAUER, F.C. Eficácia de cabines adaptadas na proteção dos operadores de tratores em aplicações de agrotóxicos na cultura da macieira. Revista de Ciências Agroveterinárias, Lages, v.9, n.1. p.109-117, 2020.
BIFFI, L.J.; MITISHITA, E.A.; LIESENBERG, V.; CENTENO, J.A.; SCHIMALSK, M.B.; RUFATO, L. Evaluating the performance of a semi-automatic apple fruit detection in a high-density orchard system using lowcost digital RGB imaging sensor. Boletim de Ciências Geodésicas, Curitiba, v. 27, n.2, $2021 \mathrm{a}$.

BIFFI, L.J.; MITISHITA, E.; LIESENBERG, V.; SANTOS, A.A.D.; GONÇALVES, D.N.; ESTRABIS, N.V.; SILVA, J.D.A.; OSCO, L.P.; RAMOS, A.P.M.; CENTENO, J.A.S.; SCHIMALSKI, M.B.; RUFATO, L.; NETO, S.L.R.; MARCATO JUNIOR, J.; GONÇALVES, W.N. ATSS abordagem baseada em aprendizado profundo para detectar maçãs. Remote Sensing, Basel, v.13, n.1, p.54, 2021b.

BITTENCOURT, C.C.; MATTEI, L.F.; SANT'ANNA, P.R.; LONGO, O.C.; BARONE, F.M. A cadeia produtiva da maça em Santa Catarina: competitividade segundo produção e packing house. Revista de Administração Pública, Rio de Janeiro, v.45, n.4, p.1199-222, 2011.

BUENO, M.P.; SILVA, A.C.; NUNES, A.L.F.P.; SARDINHA, A.C.; LIMA, P.T.S.; SILVA, J.F. Análise da comercialização da cadeia produtiva da maçã brasileira: produção, importação e exportação no período 2015 a 2019. Brazilian Journal of Development, Curitiba, v.7, n.4, p.34061-34078, 2021.

CHAVEZ, P.S., BERLIN, G.L., SOWERS, B. Método estatístico para selecionar Land-razões de MSS sat. Journal of Applied Photographic Engineering, Washington, v.8:, p.23-30, 1982.

CHAVEZ, P.S., GUPTILL, S.C., BOWELL, J.A. Técnicas de processamento de imagem para dados do mapeador temático. Proceedings ASPRS-ACSM, Bethesda, v.2, p.728-742, 1984. (Technical Paper)

CUNHA, E.R.; BACANI, V.M. Sensoriamento remoto e SIG aplicados ao mapeamento geomorfológico da bacia hidrográfica do córrego Indaiá. GEOUSP - Espaço e Tempo, São Paulo, v.19, n.3, p.630-646, 2015.

DAMASCENO, F.S; PICCININI, F.; ZANELA, A.B. A Cadeia produtiva da maçã em São Joaquim-SC sob as perspectivas: embeddedness e formação de preços e quantidades. Revista ABCustos, São Leopoldo, v.14, n.3, p.87-115, 2019.

EMBRAPA - Empresa Brasileira de Pesquisa Agropecuária. Serviço nacional de levantamento e conservação de solos. Reunião técnica de levantamento de solos. Rio de Janeiro, 1979. 83p. 
EPAGRI - Empresa de Pesquisa Agropecuária e Extensão Rural de Santa Catarina. SC conquista sua sexta indicação geográfica, da maçã fuji da Região de São Joaquim. Florianópolis, 2021. Disponível em: https://www.epagri.sc.gov.br/index.php/2021/08/03/scconquista-sua-sexta-indicacao-geografica-da-maca-fujida-regiao-de-sao-joaquim/. Acesso em: 10 ago. 2021.

ESA. GMES Sentinel-2 Mission required document. 2007. Disponível em: https://earth.esa.int/pub/ESADOC/ GMESSentinel2MRDissue2.0update.pdf. Acesso em: 29 mar. 2021.

HAWERROTH, F.J. NACHTIGALL, G.R. Maçãs: cultivo sob telas antigranizo. Revista Campo \& Negócio: HF, Uberlândia, n.170, p.114-115, 2019.

IBGE - Instituto Brasileiro de Geografia e Estatística. Levantamento sistemático da produção - LSP. 2019: maçã: produção e área colhida, Brasil e unidades da Federação. Ro de Janeiro, 2019. Disponível em: https://cidades.ibge.gov.br/brasil/sc/sao-joaquim/ pesquisa/15/11979. Acesso em: 20 maio 2021.

IBGE - - Instituto Brasileiro de Geografia e Estatística. Organização do território: malhas territoriais. Rio de Janeiro, 2021. Disponível em: https://www.ibge. gov.br/geociencias/organizacao-do-territorio/malhasterritoriais/15774-malhas.html? =\&t=downloads. Acesso em: 20 abr. 2021.

JENSEN, J. R. Sensoriamento remoto do ambiente: uma perspectiva em recursos terrestres. 2.ed. São Paulo: INEP, 2009. 672 p.

KIST, B. B.; SANTOS, C. E.; CARVALHO C.; BELING, R. R. Anuário brasileiro da maçã 2019. Santa Cruz: Editora Gazeta, 2019. 56 p.

LANDAU, E. C.; SILVA, G. A. Evolução da produção da maçã. In: EMBRAPA. Dinâmica da produção agropecuária e da paisagem natural no Brasil nas últimas décadas: produtos de origem vegetal. Brasília, DF, 2020. p.925- 949.

MARTIN, M. S.; PETRI, J. L.; BRIGHENTI, A. F. A maçã 'Fuji' da região de São Joaquim tem potencial para uma indicação geográfica? Revista Agropecuária Catarinense, Florianópolis, v.32, n.3, 2019.

MOREIRA, J.; SCHWABISCH, M.; FORNARO, G.; LANARI, R.; BAMLER, R.; JUST, D.; STEINBRECHER, U.; BREIT, H.; EINEDER, M.; FRANCESCHETTI, G.; GEUDTNER, D.; RINKEL, H. X-SAR interferometry: first results. IEEE Transactions on Geoscience and Remote Sensing, New York, v.33, n.4, p.950-956, 1995.
PEREIRA, L.B.; SIMIONI, F.J.; CARIO, S.A.F. Evolução da produção de maçã em Santa Catarina: novas estratégias em busca de maior competividade. Ensaios Fundação de Economia e Estatística. Porto Alegre, v.31, n.1, 2010.

PETRI, J.L.; HAWERROTH, F.J.; FAZIO, G.; FRANCESCATTO, P.; LEITE, G.B. Advances in fruit crop propagation in Brazil and worldwide-apple trees. Revista Brasileira de Fruticultura, Jaboticabal, v.41, n.3, 2019

PETRI, J.L.; LEITE, G.B.; COUTO, M.; FRANCESCATTO, P. Avanços na cultura da macieira no Brasil. Revista Brasileira de Fruticultura, Jaboticabal, v.33, p.48-56, 2011.

PETRI, J.L.; SEZERINO, A.A.; HAWERROTH, F.J.; PALLADINI, L.A.; LEITE, G.B.; DE MARTIN, M.S. Dormência e indução à brotação de árvores frutíferas de clima temperado. Florianópolis: Epagri, 153p. 2021 (Boletim Técnico, 192).

RABUS, B.; EINEDER, M.; ROTH, A.; BAMLER, R. The shuttle radar topography mission- a new class of digital elevation models acquired by spaceborne radar, Photogramm. Remote Sensing, Basel, v.57, p.241-262. 2003.

RECH, S.; CARIO S.A.F.; AUGUSTO, C.A. Avaliação conjuntural da produção e comercialização da maçã em Santa Catarina e no Rio Grande do Sul. Indicadores Econômicos FEE, Porto Alegre, v.42, n.1, p.81-98, 2014.

SALATINO, A. T; SANTOS, F. L. O.; PADILHA, M. R. Impactos do fenômeno el niño oscilação do sul sobre a pomicultura em Fraiburgo, SC. In: FEIRA DE ENSINO, PESQUISA E EXTENSÃO DO IFC CAMPUS FRAIBURGO, 1., 2018. Fraiburgo. Anais [...]. Fraiburgo, 2018.

STOKA, M.A.; AYUB, R.A.; SILVA, D.M.; PESSENTI, I.L.; PEREIRA, A.B.; BARBOSA, E.A.A. Effect of anti-hail nets with different colors on 'Eva' apple trees agronomical responses. Revista Brasileira de Fruticultura, Jaboticabal, v.43, n.3, 2021.

TRABAQUINI, K. MIGLIORANZA, E. FRANÇA, V. PEREIRA NETO, O. C. Caracterização de lavouras cafeeiras, utilizando técnicas de geoprocessamento e sensoriamento remoto, no município de Umuarama PR. Ciência Agrotecnologia, Lavras, v.35, n.1, p.35-44, 2011. 
WERNER, M. Shuttle Radar Topography Mission (SRTM), mission overview. Frequenz - Journal of Telecommunications, Berlin, v.55, p.75-79, 2001.

ZANELA, A.B. A dimensão de embeddedness como fenômeno precursor da produção de maça em São Joaquim - SC. Revista da FAE, Curitiba, v.22, n.1, p.51 - 66, 2019.
ZHU, Y.; YANG, G.; YANG, H.; WU, J.; LEI, L.; ZHAO, F.; FAN, L.; ZHAO, C. Identification of apple orchard planting year based on spatiotemporally fused satellite images and clustering analysis of foliage phenophase. Remote Sensing, Basel, v.12, n.7, p.1199, 2020. 